\title{
Lacrimal excretory system sequelae in patients treated for leishmaniasis
}

\author{
Alterações como seqüelas no sistema lacrimal de portadores de \\ leishmaniose tratada
}

\author{
Erika Hoyama ${ }^{1}$ \\ Silvana Artioli Schellini ${ }^{2}$ \\ Hamilton OmetoStolf ${ }^{3}$ \\ Vitor Nakajima $^{4}$
}

\begin{tabular}{|l|}
\hline ABSTRACT \\
\hline Leishmaniasis infection may involve destruction of nasal tissues resulting \\
in lacrimal drainage system alteration. Purpose: To evaluate the frequency \\
of lacrimal excretory system sequelae in patients treated for leishmaniasis. \\
Methods: Forty-five leishmaniasis-treated patients (90 nasolacrimal ducts) \\
were submitted to lacrimal excretory system evaluation. All were evaluated \\
by Jones I test and when it was abnormal, dacryocystography and nasal \\
endoscopy were performed. This situation occurred in 13 patients (26 \\
nasolacrimal ducts). Results: The majority of evaluated patients had the \\
cutaneous form (64.4\%) of leishmaniasis, however, 69.23\% of the patients \\
with lacrimal excretory system alterations had the mucocutaneous form \\
of infection before treatment. In these, the most common alteration \\
detected was bilateral permeable and dilated nasolacrimal ducts (92.30\%). \\
Only 3.84\% (1/26) of the evaluated nasolacrimal ducts were obstructed. \\
Nasal endoscopy showed turbinate hypertrophy (53.84\%), septum de- \\
viation (53.84\%) and nasal septum perforation (23.07\%). Conclusion: \\
Permeable and dilated lacrimal excretory system were the most common \\
sequelae related to leishmaniasis infection.
\end{tabular}

Keywords: Leishmaniasis/complications; Lacrimal duct obstruction/radiography; Endoscopy/methods; Nasal cavity/radiography

This study was performed at the Faculdade de Medicina de Botucatu.

${ }^{1}$ Pós-Graduanda - Departamento de Oftalmologia, Otorrinolaringologia e Cirurgia de Cabeça e Pescoço da Faculdade de Medicina da Universidade Estadual Paulista "Júlio Mesquita Filho" - UNESP - Botucatu (SP) - Brasil.

2 Professora Livre-Docente - Departamento de Oftalmologia, Otorrinolaringologia e Cirurgia de Cabeça e Pescoço da Faculdade de Medicina da UNESP - Botucatu (SP) - Brasil.

${ }^{3}$ Mestre em Otorrinolaringologia - Departamento de Oftalmologia, Otorrinolaringologia e Cirurgia de Cabeça e Pescoço da Faculdade de Medicina da UNESP - Botucatu (SP) - Brasil.

${ }^{4}$ Professor Doutor - Departamento de Dermatologia da Faculdade de Medicina da UNESP - Botucatu (SP) Brasil.

Address for correspondence: Silvana A. Schellini. DEP. OFT/ORL/CCP - Faculdade de Medicina de Botucatu - UNESP - Botucatu (SP) CEP 18618-970

E-mail: sartioli@fmb.unesp.br

Recebido para publicação em 30.03.2005

Versão revisada recebida em 20.05.2005

Aprovação em 15.12.2005

\section{INTRODUCTION}

Leishmaniasis is one of the six major endemic tropical diseases with a prevalence of 12 million cases worldwide ${ }^{(1-2)}$. The disease is widespread in Latin America where it constitutes a major public health problem. Brazil and Peru are the countries where the disease is most prevalent ${ }^{(3)}$. The highest incidence in Brazil was observed in the North, Northeast and Center-west regions $^{(1)}$.

In São Paulo state, the first reports occurred around 1908 during the construction of the Northeast railroad. Since most cases were observed close to Bauru city, the disease came to be known as "Bauru's ulcer"(4). The present study was conducted in a region $100 \mathrm{~km}$ from the city of Bauru.

There are three clinical forms of leishmaniasis infection: the cutaneous form characterized by ulcerous epidermis and single or multiple lesions confined to the dermis; the mucocutaneous form characterized by involvement of mucosa and cartilage due to direct or hematogenous dissemination and more frequently compromising nose, pharynx, mouth and larynx; and the visceral form characterized by involvement of the liver and spleen ${ }^{(4-5)}$.

Cutaneous leishmaniasis is endemic in South and Central America. The
\end{abstract}


causative agents are subspecies of $L$. braziliensis and $L$. mexicana. The spectrum of the disease ranges from a single, localized cutaneous ulcer to mucocutaneous alterations. The disease is most common in workers living at the edge of forests and in rural settlers inhabiting where the sandflies and the reservoir animals (small rodents) are abundant ${ }^{(3)}$.

Ophthalmic manifestations of leishmaniasis infection are not often observed. Eyelid ulcers occurred in 2 to $5 \%$ of patients with facial lesions ${ }^{(6-7)}$ because blinking prevents mosquito bite ${ }^{(8)}$.

Ocular involvement is rare and may happen due to the direct spread of eyelid lesions or as result of conjunctivitis ${ }^{(9-10)}$. Ulcerative keratitis ${ }^{(11)}$ and granulomatous anterior uveitis were also observed in visceral leishmaniasis ${ }^{(10,12-14)}$.

In the human lacrimal drainage system, tears flow across the eye and are drained through the upper and lower puncta which are localized at the nasal side of the upper and lower eyelids. The puncta originate the upper and lower canaliculi which have a $2 \mathrm{~mm}$ vertical portion and an $8 \mathrm{~mm}$ horizontal portion and fuse into a common canaliculus which enters the lateral wall of the lacrimal sac. The lacrimal sac has a $13-15 \mathrm{~mm}$ vertical length and originates the nasolacrimal duct which drains the tears into the lateral wall of the nose, just beneath the inferior turbinate ${ }^{(15)}$.

The alterations in the lacrimal drainage system related to leishmaniasis have rarely been reported. According to previous reports, the lid may be affected via the nasolacrimal duct, and one case with mucocutaneous infection and nasolacrimal duct stenosis associated with lacrimal fistulae, conjunctivitis and uveitis was described ${ }^{(16)}$. Baddini-Caramelli et al. showed lacrimal drainage tract involvement in 4 patients with mucocutaneous leishmaniasis, reporting dilation of lacrimal sac and nasolacrimal duct obstruction ${ }^{(17)}$.

The purpose of this study was to determine the presence of lacrimal excretory system sequelae after treatment for Leishmaniasis infection.

\section{METHODS}

This is a prospective observational study conducted at the Botucatu School of Medicine - Brazil to evaluate the frequency of lacrimal excretory system sequelae in patients treated for leishmaniasis.

Forty-five patients who started leishmaniasis treatment in 1999 were included. When the lacrimal excretory system was evaluated, all patients were already in the post-treatment period.

They were evaluated according to ocular complaints and submitted to irrigation of the nose cavities with $0.9 \%$ physiological saline to wash the nasal secretion and lacrimal excretory system evaluation by a dye test (Jones I test) consisting of instillation of one drop of $2 \%$ sodium fluorescein in both eyes and, after 5 minutes, evaluation of the presence of dye on the cotton tip inserted in the correspondent nostril. The test was considered negative when the dye was not recovered from the nostrils, suggesting a partial or complete obstruction of the nasolacrimal duct ${ }^{(15)}$.

Thirteen patients who presented an altered lacrimal excretory test were submitted to dacryocystography and nasal endoscopy.

The dacryocystographic examination consisted of dilation of the inferior lacrimal punctum using a lacrimal punctum dilator and injection of an oily radiographic contrast material (Lipiodol - Guerbet) via a cannula into the inferior canaliculus of the lacrimal drainage system. The patient was then submitted to an X-Ray which allowed us to observe good opacification of the superior, inferior, common canalicui and nasolacrimal ducts at the medial aspect of the orbit in the anteriorposterior view. Contrast could normally be seen exteriorizing into the inferior meatus where the ducts empty ${ }^{(15)}$.

Nasal endoscopy was performed using a rigid zero degree endoscope (Storz). The nasal cavity was evaluated to observe the presence of inflammation, nasal septum and/or lacrimal ostium lesions.

\section{RESULTS}

Forty-five patients treated for leishmaniasis (90 nasolacrimal ducts) were evaluated. Most of them (91.1\%) came from rural areas and $68.8 \%$ were males. Cutaneous leishmaniasis $(64.4 \%)$ was the most prevalent form observed, followed by the mucocutaneous $(31.1 \%)$ and the visceral $(4.4 \%)$ forms.

Ophthalmological complaints consisted of epiphora (24.4\%), burning (8.8\%), chronic ocular secretion (2.2\%) and refractional disorders (22.2\%); 42.4\% did not have ocular complaints.

Jones I test was abnormal in 13 patients $(28.88 \%-13 / 45)$. Of these, $69.23 \%$ had the mucocutaneous, $23.07 \%$ the cutaneous and $7.69 \%$ the visceral form of the disease before treatment. The characteristics of these patients are presented in table 1.

All patients who presented an abnormal Jones I test were submitted to dacryocystography and nasal endoscopy evaluation. The main alteration observed in the dacryocystographic examination was nasolacrimal duct dilation which was completely permeable to the contrast (Figure $1 \mathrm{~A}, \mathrm{~B}, \mathrm{C}, \mathrm{D}$ ).

The nasolacrimal duct dilation was bilateral in 11 patients (22 nasolacrimal ducts) and unilateral in two (2 nasolacrimal ducts). Thus the dilated and permeable ducts were observed in $92.30 \%$ (24/26) of the lacrimal excretory systems evaluated by dacryocystography. The lacrimal sac was dilated in one patient $(3.84 \%$ - 1/26) (Figure 2) and another (3.84\% - 1/26) presented a nasolacrimal duct obstruction.

Radiological signs of septum deviation were seen in $46.6 \%$.

Nasal endoscopy revealed turbinate bone hypertrophy (53.84\% - 7/13) and septum deviation (53.84\% - 7/13). Perforation of the septum was observed in $23.07 \%$ (3/13) and dilation of the lacrimal ostium in one patient $(6.2 \%-1 / 13)$. Collapse of the nasal pyramid was present in one patient $(6.2 \%-1 / 13)$. 


\begin{tabular}{|c|c|c|c|c|c|}
\hline Age (years) & Sex & Complaint & Clinical presentation & Dacryocystography & Endoscopy \\
\hline 58 & M & Epiphora & Mucocutaneous & Bilateral dilation. No obstruction & $\begin{array}{l}\text { Turbinate hypertrophy } \\
\text { Septum deviatium }\end{array}$ \\
\hline 69 & M & Epiphora & Cutaneous & Bilateral dilation. No obstruction & Turbinate hypertrophy \\
\hline 73 & M & Epiphora & Mucocutaneous & Unilateral dilation. No obstruction & Septum perforation \\
\hline 69 & M & Epiphora & Mucocutaneous & Bilateral dilation. No obstruction & $\begin{array}{l}\text { Turbinate hypertrophy } \\
\text { Septum deviatium }\end{array}$ \\
\hline 82 & M & $\begin{array}{l}\text { Epiphora+ } \\
\text { secretion }\end{array}$ & Mucocutaneous & Bilateral dilation. No obstruction & Septum perforation \\
\hline 55 & M & Epiphora & Cutaneous & Unilateral dilation. No obstruction & $\begin{array}{l}\text { Turbinate hypertrophy } \\
\text { Septum deviatium }\end{array}$ \\
\hline 12 & M & None & Mucocutaneous & Bilateral dilation. No obstruction & None \\
\hline 11 & $\mathrm{~F}$ & None & Mucocutaneous & Bilateral dilation. No obstruction & None \\
\hline 65 & M & Epiphora & Mucocutaneous & Bilateral dilation. No obstruction & $\begin{array}{l}\text { Turbinate hypertrophy } \\
\text { Septum deviatium }\end{array}$ \\
\hline 37 & M & None & Cutaneous & Bilateral dilation. No obstruction & $\begin{array}{l}\text { Turbinate hypertrophy } \\
\text { Septum deviatium }\end{array}$ \\
\hline 28 & M & None & Visceral & Bilateral dilation. No obstruction & $\begin{array}{l}\text { Turbinate hypertrophy } \\
\text { Septum deviatium }\end{array}$ \\
\hline 62 & M & None & Mucocutaneous & Bilateral dilation. No obstruction & Septum deviatium \\
\hline 67 & $\mathrm{~F}$ & Epiphora & Mucocutaneous & Bilateral dilation and obstruction & Septum perforation \\
\hline
\end{tabular}

\section{DISCUSSION}

More than half of the 45 patients evaluated in this study presented the cutaneous form of leishmaniasis. The majority lived in rural areas close to the city of Bauru where the transmitting mosquito was easily found and from where came the first reports of the disease in Brazil. The infection was also more prevalent in men, probably because they usually spend more time working outside.

L. braziliensis is the main agent responsible for leishmaniasis disease in Brasil and can persist after the disappearance

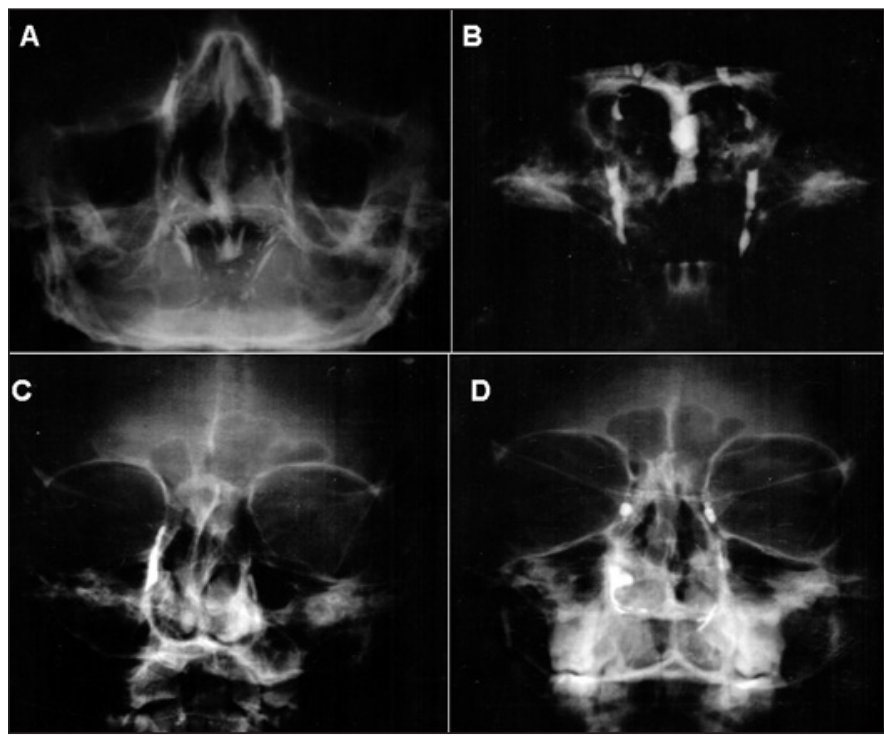

Figure 1 - A, B, C, D: Dacryocystographic evaluation of patients with leishmaniasis with permeable and dilated lacrimal excretory system of the primary cutaneous ulcer and subsequently appears as a mutilating mucosal infection. It causes destruction of the nasal and labial tissues and various lesions can be observed all over the body. The nasopharyngeal region may be involved concomitantly with or after the initial cutaneous infection during the disease ${ }^{(3)}$. All patients included in this study were already in the post-treatment period; therefore, as expected, nasal inflammation was not observed.

As leishmaniasis infection may affect mucous tissues, we decided to evaluate the lacrimal excretory system of treated patients.

The basic lacrimal excretory system evaluation begins with the non-invasive procedures (screening tests), one of which

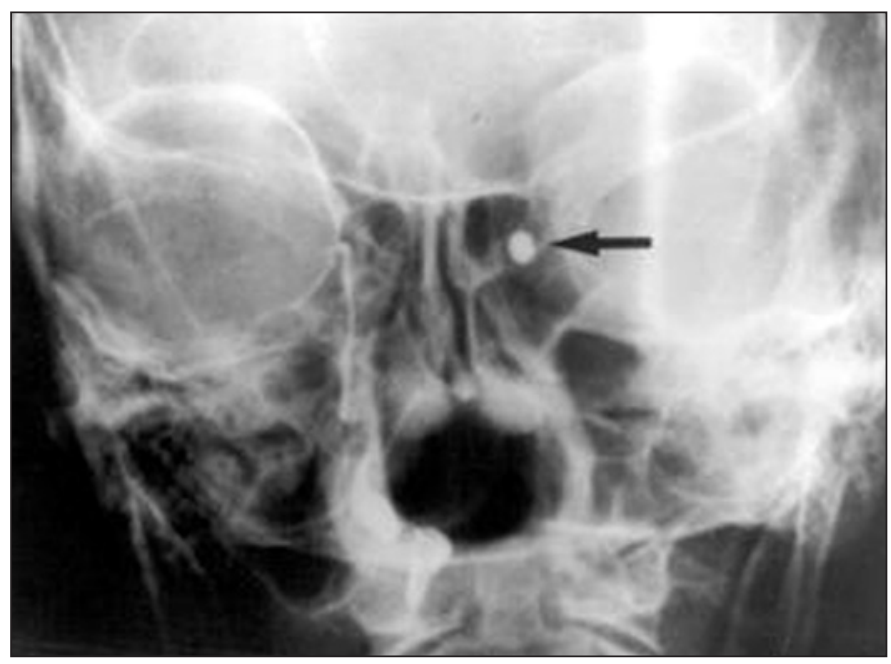

Figure 2 - Dacryocystographic evaluation showing a patient with leishmaniasis with lacrimal obstruction and lacrimal sac dilation (arrow) in the left side and nasal septum perforation 
is the Jones I test described in this study. The patients who present abnormal screening tests are then submitted to the more invasive tests, like the dacryocystographic examination.

Dacryocystography is only performed on patients with the strong probability of lacrimal drainage system alteration. It is not indicated for normal patients because it is an invasive procedure, costly regarding both time and money. In addition, patients have to be submitted to exposure to radiation. For these reasons we did not include a control group with normal patients, and only performed dacryocystographic examinations in patients who presented an abnormal Jones I test.

The normal lacrimal sac is the most dilated portion of the lacrimal excretory system ${ }^{(15)}$, and those who presented any portion of their diameters greater than the lacrimal sac were considered dilated nasolacrimal ducts.

Thirteen of our patients presented an altered lacrimal excretory dye test (Jones I test). The nasolacrimal ducts may be affected by direct, hematogenous or lymphatic dissemination $^{(6,18)}$, depending on the type of clinical manifestation, and their involvement is mainly observed in patients with the mucocutaneous form of the disease, as observed here. In the present study, $80 \%$ of the patients who presented obstruction by the lacrimal excretory test had had the mucocutaneous form.

The main alteration observed in the lacrimal excretory system was a complete permeable lacrimal drainage tract with nasolacrimal duct dilation. Only one patient had lacrimal excretory system obstruction and lacrimal sac dilation.

There are many possible explanations for the nasal mucosal disease. Often it starts in the septum as a slight swelling and reddening of the mucosa and progresses slowly over time to result in perforation and destruction of the septum evolving to nose collapse ${ }^{(3)}$.

In this study, many patients had nasal alterations which might explain the nasolacrimal duct alterations. The "tapir" nose was observed in one patient and nasal endoscopy showed nasal septum perforation and dilated lacrimal ostium too.

An inflammatory process of the distal portion of the lacrimal drainage tract, the mechanical obstruction caused by nasal scabs or nasal collapse could be possible causes for lacrimal excretory system dysfunction ${ }^{(17)}$ and consequent obstruction.

Common symptoms of leishmaniasis affecting the ocular region include tearing and purulent discharge, and conjunctivitis usually occurs as a result of direct extension of the lid infection or through the hematogenous route ${ }^{(13)}$. However, lacrimal drainage system obstruction might be another cause of chronic eye discharge.

The authors intend to show that chronic dacryocystitis can be a possible complication of leishmaniasis infection, but that few cases have been reported, probably because of misdiagnosis.

In conclusion, our results show that the most frequent lacrimal drainage alteration in leishmaniasis-treated patients is nasolacrimal duct dilation without obstruction, occurring mainly as a sequela of the mucocutaneous form of leishmaniasis infection.

\section{RESUMO}

A leishmaniose pode destruir os tecidos nasais resultando em alterações da via lacrimal excretora. Objetivo: Avaliar a ocorrência de alterações do sistema lacrimal excretor em portadores de leishmaniose na fase de pós-tratamento. Métodos: Foi realizada a avaliação da via lacrimal excretora em 45 portadores de leishmaniose tratada (90 vias lacrimais) pelo teste de Jones I. Treze pacientes (26 ductos nasolacrimais) tiveram o teste de Jones I alterado, tendo sido submetidos a dacriocistografia e endoscopia nasal. Resultados: A maioria dos indivíduos avaliados apresentava a leishmaniose na forma cutânea $(64,4 \%)$. Entretanto, 69,23\% dos indivíduos com alteração do sistema lacrimal excretor apresentavam a forma mucocutânea antes do tratamento. A alteração mais freqüentemente detectada foi ducto nasolacrimal permeável e dilatado (92,30\%). Apenas $3,84 \%$ (1/26) das vias lacrimais estavam obstruídas. A endoscopia nasal mostrou hipertrofia de corneto $(53,84 \%)$, desvio de septo $(53,84 \%)$ e perfuração do septo nasal $(23,07 \%)$. Conclusão: Em portadores de leishmaniose tratada encontra-se como sequiela mais freqüente no sistema excretor lacrimal as vias lacrimais permeáveis e dilatadas.

Descritores: Leishmaniose/complicações; Obstrução dos ductos lacrimais/radiografia; Endoscopia/métodos; Cavidade nasal/radiografia

\section{REFERENCES}

1. National Health Foundation. Epidemiologic Vigilance Guide: 5.16. American Cutaneous Leishmaniasis; 5.17. Visceral Leishmaniasis. [text on the Internet] 4th ed. Brasília; 1996 [cited 2005 Ago 9]. Available at: URL: http://www. funasa.gov.br/pub/gve/gve 0516A.htm.

2. Control of the leishmaniases. Report of a WHO Expert Committee. World Health Organ Tech Rep Ser. 1990;793:1-158.

3. Pearson RD, Sousa AQ. Leishmania species-visceral (kala-azar), cutaneous, and mucosal leishmaniasis. In: Mandell GL, Douglas Jr. RG, Bennett JE, editors. Principles and practice of infectious diseases. 3rd ed. New York: Churchill Livingstone; 1990. p.2066-77.

4. Neves DP. Parasitologia humana. 10a ed. São Paulo: Atheneu; 2000.

5. Manson-Bahr PEC, Bell DR. Manson's tropical diseases. 19th ed. London; Philadelphia: Baillière Tindall; 1987.

6. Abboud IA, Ragab HA, Hanna LS. Experimental ocular leishmaniasis. Br J Ophthalmol. 1970;54(4):256-62.

7. Oliveira-Neto MP, Martins VJ, Mattos MS, Pirmez C, Brahin LR, Benchimol E. South American cutaneous leishmaniasis of the eyelids: report of five cases in Rio de Janeiro State, Brazil. Ophthalmology. 2000;107(1):169-72.

8. Morgan G. Case of cutaneous leishmaniasis of the lid. Br J Ophthalmol. 1965; 49(10):542-6.

9. Roizenblatt J. Interstitial keratitis caused by American (mucocutaneous) leishmaniasis. Am J Ophthalmol. 1979;87(2):175-9.

10. el Hassan AM, Khalil EA, el Sheikh EA, Zijlstra EE, Osman A, Ibrahim ME. Post kala-azar ocular leishmaniasis. Trans R Soc Trop Med Hyg. 1998;92(2): 177-9.

11. Duke-Elder S, Leigh AG. Diseases of the outer eye, cornea and sclera. In: DukeElder S, editor. System of ophthalmology. London: Kimpton; 1965. p.811-56.

12. Dechant W, Rees PH, Kager PA, Klauss V, Adala H. Post kala-azar uveitis. Br J Ophthalmol. 1980;64(9):680-3.

13. el-Hassan AM, el-Sheikh EA, Eltoum IA, Ghalib HW, Ali MS, Zijlstra E, Satti MM. Post-kala-azar anterior uveitis: demonstration of Leishmania parasites in the lesion. Trans R Soc Trop Med Hyg. 1991;85(4):471-3. 
14. Oréfice JL, Oréfice F, Lasmar EP, Gontijo CMF. Uveíte difusa bilateral causada por Leishmania braziliensis. Rev Bras Oftalmol. 1999;58(1):65-9.

15. Milder B. Pruebas diagnósticas del funcionalismo lagrimal. In: Weil BA, Milder B. editor. Sistema lacrimal. São Paulo: Medicina Panamericana; 1970. p.84-91.

16. Machado NR, Machado JGC, Moura PA. Sobre um caso de leishmaniose ocular. Rev Bras Oftalmol. 1958;17(1):5-20.
17. Baddini-Caramelli C, Matayoshi S, Moura EM, Araf D, Santo R, Voegels R, Kara-José N. Chronic dacryocystitis in American mucocutaneous leishmaniasis. Ophthal Plast Reconstr Surg. 2001;17(1):48-52.

18. Bittencourt AL, Barral A. Evaluation of the histopathological classifications of American cutaneous and mucocutaneous leishmaniasis. Mem Inst Oswaldo Cruz. 1991;86(1):51-6.

\section{Simpósio de Oftalmologia da UNIFESP}

\section{Instituto da Visão}

\section{3 a 5 de Agosto de 2006}

LOCAL:

GRAN MELIÁ MOFARREJ

Al. Santos, 1437 - São Paulo (SP)

\section{TEMA: NOVAS HEGNOLOCLAS}

\section{CURSOS E SIMPÓSIOS:}

- Atualização Clínica e Cirúrgica nas diversas áreas da Oftalmologia

- Programas de imersão no Pré-Congresso

- Atualização em Clínica Médica para oftalmologistas

- Atualização em Medicina Celular e Células-tronco aplicadas à Oftalmologia

- Cirurgias ao vivo

- Wet Labs

- Investimentos e Finanças pessoais 